\title{
A bibliometric analysis of the fuzzy front-end of innovation using the HistCite software
}

\author{
Maicon Gouvêa de Oliveira ${ }^{a}$ Glauco Henrique de Souza Mendes ${ }^{b}$ \\ aFederal University of Alfenas \\ bFederal University of São Carlos \\ e-mails: maicongdo@gmail.com; glauco@dep.ufscar.br
}

\begin{abstract}
The number of academic papers addressing the fuzzy front-end (FFE) of innovation has increased over the last years, confirming the importance of this research field. This paper presents the outcomes of a bibliometric analysis of the literature related to FFE that was published between 1985 and 2013. The HistCite software was the tool used to implement the analysis. The results show the number of papers published per year, the most important journals, and the most cited papers. Most of the studies reviewed in this article applied empirical research methods, and the number of research topics have increased in this period. This study provides a preliminary bibliometric and thematic analysis of the FFE literature, identifying research perspectives.
\end{abstract}

Keywords: front-end, innovation, bibliometric, literature review.

\section{Introduction}

The fuzzy front end (FFE) of innovation embraces the early stages of the innovation process. Its activities lie between the idea generation and the decision regarding the development or termination of a product proposal (COOPER, 1988). According to Khurana and Rosenthal (1997), the FFE includes: the formulation of a new product strategy, opportunity identification, generation and screening of ideas, product definition and project planning.

Several authors have discussed the importance of the FFE (KHURANA; ROSENTHAL, 1998; KIM; WILEMON, 2002; BACKMAN; BORJESSON; SETTERBERG, 2007; VERWORN; HERSTATT; NAGAHIRA, 2008; MARKHAM, 2013). They have claimed these early stages as being the primary opportunity to enhance innovation outcomes. Moreover, the FFE requires often less effort to reduce time, resources and costs if compared to the other innovation stages.

In spite of being an opportunity for improvement, the execution and management of FFE is complex and unclear. Khurana and Rosenthal (1998), Koen et al. (2002) and Markham et al. (2010) described the FFE as a path of complex information processing, tacit knowledge, conflicting organizational roles and uncertainty. According to them, the development of knowledge that suits to the specific FFE characteristics and requirements is required to overcome these issues.

The number of academic papers addressing the FFE has increased over the last years, confirming the importance of this research field. However, the studies developed seem to lack alignment, leading to poor achievements in new theory building. This fact indicates the need of a better understanding of the research field, supporting the establishment of more appropriate research lines.

A first step toward the understanding of the FFE research field consists of performing a comprehensive analysis of the state of the art. Some attempts have been done in this sense, however they tend to focus on specific topics and, therefore, provide restricted guidance (KIM; WILEMON, 2002; CHANG; CHEN; WEY, 2007). Concerning the entire research field, no attempt aiming at clarifying it has been found during the development of this study.

To tackle issue, this paper presents a bibliometric analysis of the research field of the fuzzy front end of innovation. As a result, an overview of the state of the art is provided as well as some directions for future research.

The following section describes the research method followed in the study. Then, the results of the bibliometric analysis are presented and discussed. Finally, conclusions are drawn and future research is suggested.

\section{Research method}

This paper represents a systematic literature review of the front end of innovation. Cook, Mulrow and Haynes (1997) argue that the systematic literature review employs research methods with greater scientific rigor. Therefore, it is likewise to achieve better results, since minimizes errors and bias in the research process. Bibliometrics is a core part of systematic reviews, providing information about 
the state of the art through the investigation of the scientific production. Scientific databases are the main source of data, being used to establish indicators through the application of quantitative techniques (OKUBO, 1997).

Bibliometrics refers to the mathematical and statistical analysis of the publication data, for example: the most important academic papers and the main authors and journals based on a citation analysis (OKUBO, 1997). It can also include content analysis, since it allows the identification of the most important research topics, approaches and methods (RAMOS-RODRÍGUEZ; RUÍZ-NAVARRO, 2004).

The systematic literature review conducted in this study selected the Web of Science ${ }^{\ominus}$ database as the source of data. This database embraces an extensive collection of journals within the FFE research field as well as it provides the metadata required to load the $\mathrm{HistCite}^{\oplus}$, the bibliometric tool chosen for this study. There are other bibliometric studies which have focused on the Web Science ${ }^{\odot}$ database (CARVALHO; FLEURY; LOPES, 2013).

The following keywords were selected to search the initial sample: "front end", "predevelopment" and "pre development". In addition, the sample was restricted to papers of journal published between 1985 and 2013 and classified within the categories: business, management, industrial engineering, operation research/management science. As a result, a total of 333 papers were identified.

Afterwards, abstracts were read and assessed, aiming at removing papers whose subject did not fit to the study. At this point, the screening process involved two researchers, working in parallel and comparing their judgments. Then, 217 were excluded, leading to a final sample of 116 papers. The list containing these papers is presented in Appendix 1.

The HistCite ${ }^{\odot}$ bibliometric tool was chosen to support the bibliometric analysis. This tool provides a set of predefined analysis, which was carried out to explore the final sample: number of papers published per year; the most important journals, the most cited authors and institutions; the most cited papers; citation network; the most cited references and the most used words in titles and keyword.

At the end, a content analysis was undertaken to extract information concerning research methods and research lines addressed in the FFE research field. In this sense, the content of papers was analysed by the researchers and data were collected, grouped and classified according to a classification scheme proposed in this study. Content analysis method has also been used to underpin other literature reviews (CARVALHO; FLEURY; LOPES, 2013). Table 1 shows the proposed classification scheme.

The first part of the classification scheme follows the Papastathopoulou and Hultink (2012) approach, in which research methods are classified in conceptual and empirical. The conceptual comprises literature reviews, theoretical models, frameworks, quasi-experiment and simulations. The empirical includes surveys, case studies and action researches. The second part of the scheme deals with research lines. At this point, the proposal was developed through a bottom-up approach, in which research topics were gathered and grouped, leading to major categories, i.e., research lines. The next section presents the results of the bibliometric analysis.

\section{Bibliometric analysis}

As aforementioned, the bibliometric analysis was performed through the application of the HistCite ${ }^{\odot}$ software. The sample is comprised of 116 journal papers collected from the Web of Science $^{\oplus}$ database and described in Appendix 1. The following metrics were developed:

- number of papers published per year

- the most important journals, authors and institutions

- the most cited papers

- the citation network

- the most cited references

- the most used words in titles and keywords

These metrics are presented and discussed throughout this section.

\subsection{Number of papers published per year}

This study considered papers published between 1985 and 2013, which means a time span of 28 years. Figure 1 shows the histogram of papers throughout the years as well as a tendency line base on the moving average of three periods, which aims at clarifying the evolution of the research field.

The histogram depicts a nonlinear growing of publications in the FFE, with peaks of 15 and 18 papers, respectively in 2011 and 2012. It can be noticed a low profile period from

Table 1. Classification Scheme for Research Methods and Research Lines.

\begin{tabular}{|l|l|}
\hline \multicolumn{1}{|c|}{ Research Methods } & \multicolumn{1}{c|}{ Research Lines } \\
\hline RM1 - Literature review & RL1 - Organizational issues \\
\hline RM2 - Theoretical Model or Simulation & RL2 - Process and Information \\
\hline RM3 - Survey & RL3 - Critical success factors and performance \\
\hline RM4 - Case study & RL4 - Customer involvement \\
\hline RM5 - Action research & RL5 - Tools and methods \\
\hline RM6 - Multiple methods & RL6 - Others \\
\hline
\end{tabular}


1988 to 2005 , in which a total of 35 papers were published and the average of papers per year was 2,059. Additionally, an important fact seems to have affected positively the research field just before 2002, since a large increase in the number of published papers occurred this year. The sample was verified in terms of an unusual journal participation in this year, for example, a special issue addressing the FFE, but nothing was identified.

The following period indicates a significant growth in the FFE research field. From 2006 to 2013, a total of 81 papers were published, representing an average of 10,125 papers per year, almost 5 times the average the first period. In addition, 2011 and 2012 shows outstanding performance, with 15 and 18 papers respectively. The Journal of Product and Innovation Management (IJPIM) contributed with 9 papers in these two years, suggesting its further interest in the field. In 2013, a drop on the number of published papers occurred. This fact can either indicate a decrease of studies or an unusual peak in 2011 and 2012.

\subsection{The most important journals, authors and institutions}

Three metrics are considered in this section: journals, authors and institutions. A total of 44 journals were part of the sample considered in this study, being that only 11 of them embrace at least three papers, as described in Table 2. In addition, only four of them embrace $45.7 \%$ of the published papers. This information is relevant, since it can infer a concentration of the FFE knowledge.

Following, a total of 242 authors were assigned to the papers considered in the sample, being that only 10 of them have contributed with at least 3 papers, as describe in Table 3. This result can suggest little commitment of authors, since their majority does not continue to publish in the research field.

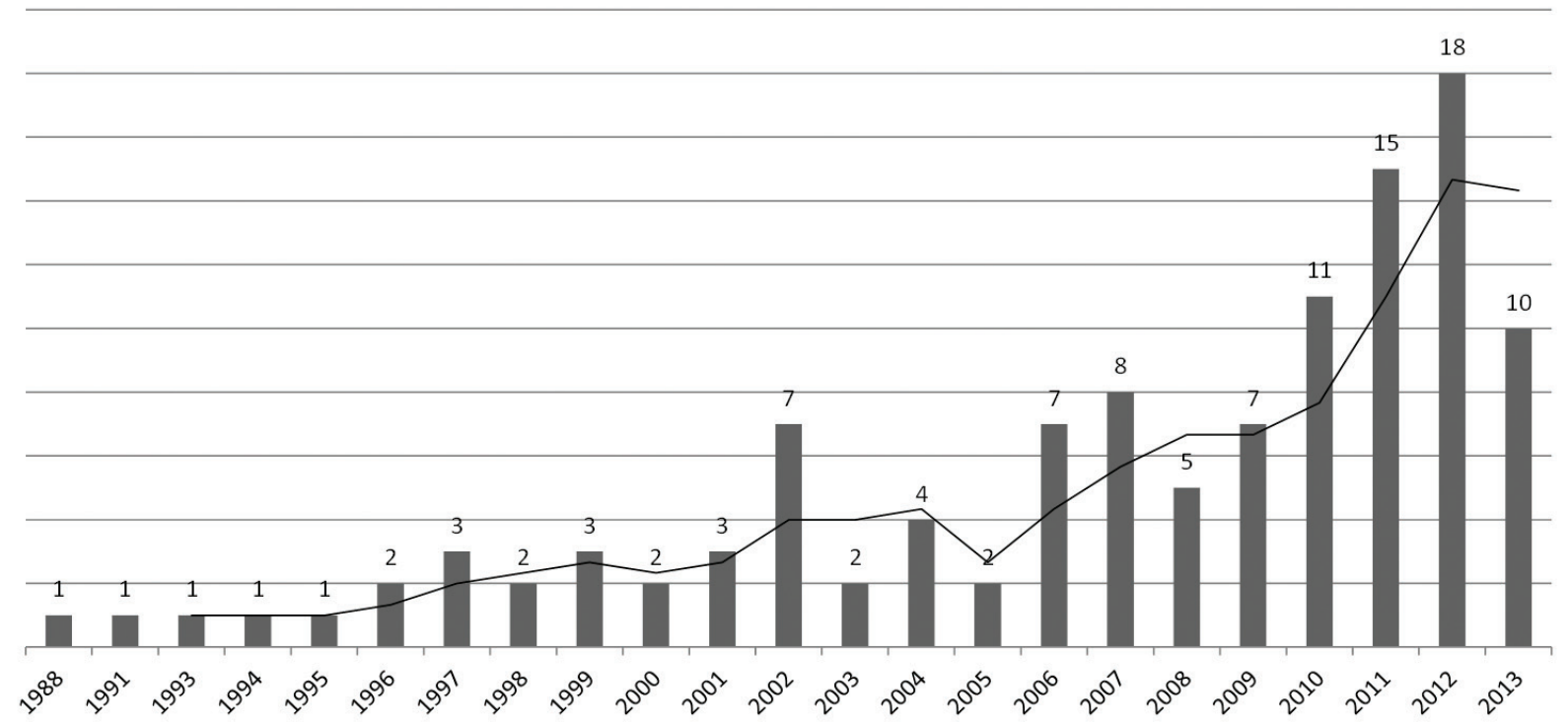

Figure 1. Histogram of papers in the FFE research field from 1985 to 2013.

Table 2. Number of papers published per journal.

\begin{tabular}{|l|c|c|}
\hline \multicolumn{1}{|c|}{ Journals } & Numberof Papers & Percentage of the Sample \\
\hline Journal of Product Innovation Management & 21 & 18.1 \\
\hline R\&D Management & 12 & 10.3 \\
\hline Research-Technology Management & 11 & 9.5 \\
\hline International Journal of Technology Management & 9 & 7.8 \\
\hline IEEE Transactions on Engineering Management & 5 & 4.3 \\
\hline Technovation & 5 & 4.3 \\
\hline Expert Systems with Applications & 4 & 3.4 \\
\hline International Journal of Project Management & 4 & 3.4 \\
\hline Creativity and Innovation Management & 3 & 2.6 \\
\hline Industrial Marketing Management & 3 & 2.6 \\
\hline Journal of Engineering and Technology Management & 3 & 2.6 \\
\hline
\end{tabular}


Then, a total of 139 institutions were responsible for the selected papers, being that only 8 presented at least three papers, as described in Table 4. This result clarifies the universities and countries in which the FFE has been the focus of research.

\subsection{The most cited papers}

This section addresses the most cited papers from two perspectives: local score citation (LCS) and global score citation (GCS). The LCS considers the most cited papers within the chosen sample. The GCS embraces the most cited papers within Web of Science ${ }^{\odot}$, denoting those that were important not only for the FFE, but to other fields.

Based on the LCS, 20 papers were cited at least 5 times for others, including self-citations. This list is presented in Table 5.

The GCS provides significant changes in the most cited papers. In this metric, the number of papers cited at least 5 times increases to 70 and, therefore, the threshold needs to be redefined to effectively highlight the most important ones. Consequently, at this time only papers cited at least 20 times were considered, which lead to the 34 papers presented in Table 6 .

There are points for discussion about the papers in Tables 5 and 6. First of all, 16 papers are in both tables, indicating they have influenced papers within and outside

Table 3. Number of papers published by author.

\begin{tabular}{|l|c|c|}
\hline \multicolumn{1}{|c|}{ Authors } & Number of Papers & $\begin{array}{c}\text { Percentage of the } \\
\text { Sample }\end{array}$ \\
\hline Frishammar J. & 4 & 3,4 \\
\hline De Brentani U. & 3 & 2,6 \\
\hline Herstatt C. & 3 & 2,6 \\
\hline Lichtenthaler U. & 3 & 2,6 \\
\hline Montoya-Weiss M.M & 3 & 2,6 \\
\hline O'driscoll T.M. & 3 & 2,6 \\
\hline Poskela J. & 3 & 2,6 \\
\hline Reid S.E. & 3 & 2,6 \\
\hline Rosenthal S.R. & 3 & 2,6 \\
\hline Verworn B. & 3 & 2,6 \\
\hline
\end{tabular}

the FFE research field boundaries. These papers are not marked with signals in the number of citations column. Secondly, the marked papers appear only at one table, i.e., are either important to the FFE or to other fields incorporated in the database. On one side, three papers seem to be important only to the FFE: Smith, Herbein and Morris (1999), Borjesson et al. (2006) and Verworn (2006). On the other side, looking at the papers mostly used in other fields, they seem to be important for the new product development and innovation management research fields. This fact was already expected, since the FFE refers to the early stages of the innovation and new product development process (OLIVEIRA et al., 2011).

\subsection{The citation network within the sample}

The citation analysis can provide an overview of possible research networks in the FFE research field. To this end, a citation network was developed considering a threshold of 5 citations for the local citation score, which correspond to papers described in Table 5. This network is presented in Figure 2, in which the number between brackets is the amount of papers per year. The papers related to each node are described in Table 5

The network shows that the papers indicated by the nodes 1 (COOPER, 1988), 5 (KHURANA; ROSENTHAL, 1997), 7 (SMITH; HERBEIN; MORRIS, 1999), 9 (KOEN et al., 2001) and 14 (LANGERAK; HULTINK; ROBBEN, 2004) seem to be the starting points of the FFE research field. All other papers were affected by at least another paper. Additionally, the network presents central nodes, i.e., papers integrating research topics. The papers of nodes 11 (KIM; WILEMON, 2002), 14 (LANGERAK; HULTINK; ROBBEN, 2004) and 19 (VERWORN; HERSTATT; NAGAHIRA, 2008) cited at least 5 others papers in the network and, therefore, are considered as central nodes.

\subsection{The most cited references}

A total of 4.215 references were cited in the sample. From these, only 23 references, which were not already part of the sample, were cited more than 10 times. At this time,

Table 4. Number of papers published by institution.

\begin{tabular}{|l|c|c|c|}
\hline \multicolumn{1}{|c|}{ Institutions } & Country & Number of Papers & Percentage of the Sample \\
\hline Delft University of Technology & The Netherlands & 6 & 5,2 \\
\hline North Carolina State University & USA & 5 & 4,3 \\
\hline Lappeenranta University of Technology & Finland & 4 & 3,4 \\
\hline Lulea University of Technology & Sweden & 4 & 3,4 \\
\hline Boston University & USA & 3 & 2,6 \\
\hline Carleton University & Canada & 3 & 2,6 \\
\hline Concordia University & Canada & 3 & 2,6 \\
\hline University of Mannhein & Germany & 3 & 2,6 \\
\hline
\end{tabular}


Table 5. List of the 20 most cited papers based on the local score citation.

\begin{tabular}{|c|c|c|}
\hline Paper & Number of Citations & Number for the Citation Network \\
\hline Khurana and Rosenthal (1998) & 41 & 6 \\
\hline Khurana and Rosenthal (1997) & 39 & 5 \\
\hline Reid and Brentani (2004) & 33 & 13 \\
\hline Koen et al. (2001) & 30 & 9 \\
\hline Kim and Wilemon (2002) & 29 & 11 \\
\hline Moenaert et al. (1995) & 26 & 2 \\
\hline Cooper (1988) & 21 & 1 \\
\hline Murphy and Kumar (1997) & 14 & 4 \\
\hline Reinertsen (1999) & 13 & 8 \\
\hline Verworn, Herstatt and Nagahira (2008) & 10 & 19 \\
\hline Langerak, Hultink and Robben (2004) & 10 & 14 \\
\hline Alam (2006) & 9 & 16 \\
\hline Dahl and Moreau (2002) & 7 & 10 \\
\hline Stevens and Burley (2003) & 7 & 12 \\
\hline Song and Parry (1996) & 5 & 3 \\
\hline Rosenthal and Capper (2006) & 5 & 17 \\
\hline Poskela and Martinsuo (2009) & 5 & 20 \\
\hline Borjesson et al. (2006) & $5 *$ & 18 \\
\hline Smith, Herbein and Morris (1999) & $5 *$ & 7 \\
\hline Verworn (2006) & $5 *$ & 15 \\
\hline
\end{tabular}

*papers checked do not appear in Table 6 .

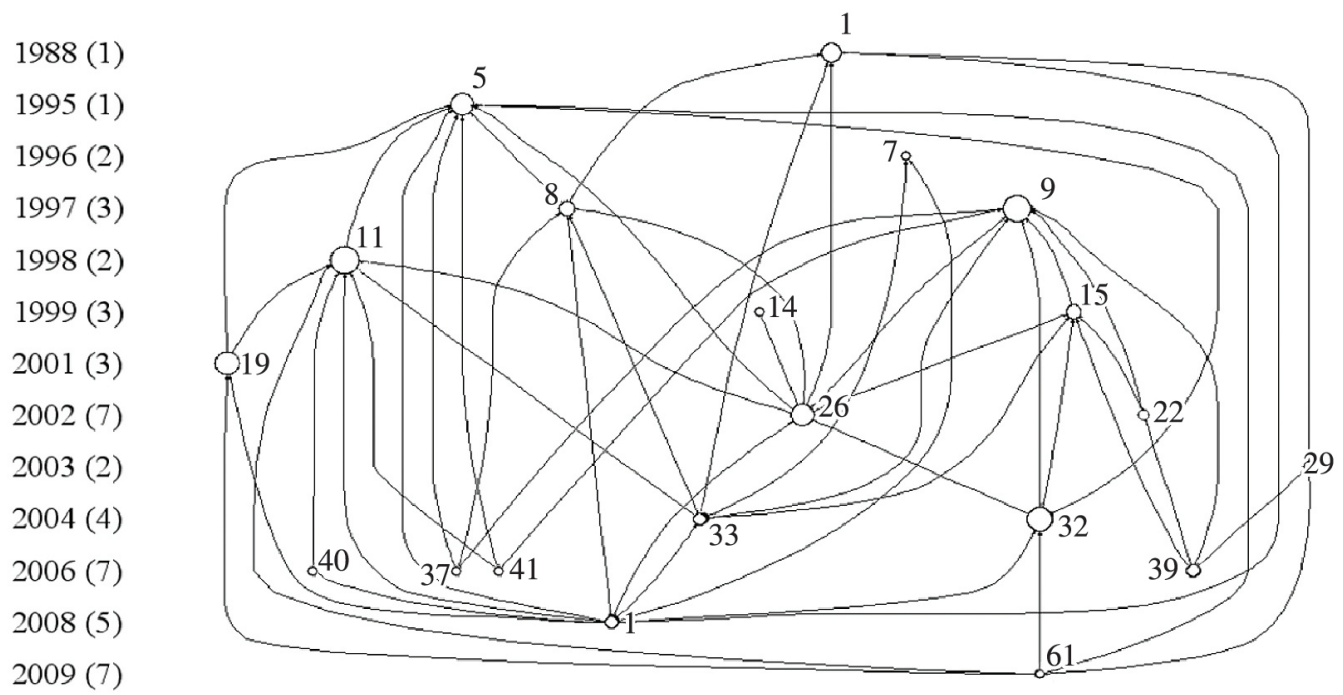

Figure 2. Citation network based on the local citation score.

books were considered among the most cited references, as described in Table 7.

A further analysis of the cited references revealed new papers addressing the FFE research field, which were uncovered in the Web of Science ${ }^{\odot}$ database. In fact, these papers are also important to understand the field, indicating a limitation of the method adopted in this study. In order to cope with this limitation, the references cited at least 5 times in the sample, which correspond to a total of 142 references, were checked aiming at collecting new papers concerning the FFE. Then, other 17 papers should have been included as part of the sample, but have not. These papers are presented in Table 8.

It should be noticed that these new papers were not loaded in the bibliometric analysis, due to restrictions of the bibliometric tool to load metadata of papers not included in the Web of Science ${ }^{\oplus}$. This fact can hinder to some extent the results of the bibliometric analysis and, therefore, represents a key limitation of this study. 
Table 6. List of the 34 most cited papers based on the global citation score.

\begin{tabular}{|c|c|}
\hline Paper & $\begin{array}{c}\text { Number of } \\
\text { Citations }\end{array}$ \\
\hline Khurana and Rosenthal (1998) & 140 \\
\hline Koen et al. (2001) & 130 \\
\hline Khurana and Rosenthal (1997) & 129 \\
\hline Reid and Brentani (2004) & 121 \\
\hline Dahl and Moreau (2002) & 116 \\
\hline Groenveld (1997) & $112 *$ \\
\hline Song and Parry (1996) & 89 \\
\hline Cooper (1988) & 88 \\
\hline Kim and Wilemon (2002) & 82 \\
\hline Moenaert et al. (1995) & 75 \\
\hline Alam (2006) & 73 \\
\hline Massey, Montoya-Weiss and O'driscoll (2002b) & $62 *$ \\
\hline Cooper, Edgett and Kleinschmidt (2002) & $53 *$ \\
\hline Salomo, Weise and Gemuenden (2007) & $52 *$ \\
\hline Montoya-Weiss and O'driscoll (2000) & $47 *$ \\
\hline Murphy and Kumar (1997) & 38 \\
\hline Rice et al. (2001) & $36 *$ \\
\hline Verworn, Herstatt and Nagahira (2008) & 35 \\
\hline Flint (2002) & $35 *$ \\
\hline Ayag (2005) & $35 *$ \\
\hline Reinertsen (1999) & 33 \\
\hline Stevens and Burley (2003) & 33 \\
\hline Van Riel et al. (2011) & $33 *$ \\
\hline Rosenthal and Capper (2006) & 31 \\
\hline Loch et al. (2001) & $30 *$ \\
\hline Ozer (2005) & $28 *$ \\
\hline Van Aken and Weggeman (2000) & $26 *$ \\
\hline Broering et al. (2006) & $25 *$ \\
\hline Lin and Chen (2004) & $24 *$ \\
\hline Langerak, Hultink and Robben (2004) & 23 \\
\hline Gerwin (1993) & $22 *$ \\
\hline Poskela and Martinsuo (2009) & 21 \\
\hline Griffiths-Hemans and Grover (2006) & $21 *$ \\
\hline Brem and Voigt (2009) & $20 *$ \\
\hline
\end{tabular}

*papers checked do not appear in Table 5.

\subsection{The most used words in titles and keywords}

Finally, the analysis of titles and keywords confirms the sample fits to the FFE research field, since the words: product, development, front, innovation, end, fuzzy, new, success, performance and communication appear as the 10 most used. These words and their number of citations in the sample are described in Table 9.

In addition, a further analysis of the most cited words could indicate topics commonly embraced in the FFE research field, i.e., subjects being dealt within the field. A content analysis was developed to address appropriately this issue, as introduced in the next section.
Table 7. List of references outside the sample and cited at least 10 times.

\begin{tabular}{|l|c|c|}
\hline \multicolumn{1}{|c|}{ Papers } & $\begin{array}{c}\text { Number of } \\
\text { Citations }\end{array}$ & $\begin{array}{c}\text { Reference } \\
\text { Type }\end{array}$ \\
\hline Brown and Eisenhardt (1995) & 19 & Paper \\
\hline Cooper (1987) & 18 & Paper \\
\hline Zhang and Doll (2001) & 17 & Paper \\
\hline Cooper and Kleinschmidt (1986) & 16 & Paper \\
\hline Smith and Reinertsen (1991) & 16 & Book \\
\hline Clark and Fujimoto (1991) & 15 & Book \\
\hline Cooper (1993) & 15 & Book \\
\hline Griffin (1997) & 15 & Paper \\
\hline Hippel (1986) & 14 & Paper \\
\hline Wheelwright and Clark (1992) & 14 & Book \\
\hline Veryzer (1998) & 13 & Paper \\
\hline Bacon et al. (1994) & 12 & Paper \\
\hline Cohen and Levinthal (1990) & 12 & Paper \\
\hline Eisenhardt (1989) & 12 & Paper \\
\hline Garcia and Calantone (2002) & 12 & Paper \\
\hline Galbraith (1973) & 11 & Book \\
\hline Nobelius and Trygg (2002) & 11 & Paper \\
\hline Armstrong and Overton (1977) & 10 & Paper \\
\hline Cooper (1994) & 10 & Paper \\
\hline Cooper (2001) & 10 & Book \\
\hline Dwyer and Mellor (1991) & 10 & Paper \\
\hline Eisenhardt and Tabrizi (1995) & 10 & Paper \\
\hline Yin (1994) & 10 & Book \\
\hline
\end{tabular}

\section{Content analysis of research methods and research lines}

The content analysis followed the classification scheme presented in the research method section. This scheme defines categories for sorting research methods and research lines encountered in the sample.Based on it, the papers were firstly separated between empirical and conceptual research methods. As shown in Table 10, 89 papers adopted empirical methods, being that: 52 of them used a qualitative approach based in a single or multiple cases; 32 applied survey methods, which are quantitative in nature; 3 conducted mixed approaches, since they applied jointly case studies and survey; and 2 were action researches. The conceptual methods accounted for 27 papers. A total of 20 were classified as theoretical models, frameworks, quasi-experiment or simulations, whereas 7 papers were classified as literature reviews or purely theoretical studies.

The analysis of research methods suggests that studies were predominantly empirical and quantitative in the beginning of the research field. The papers in this period (RUBENSTEIN, 1994; MOENAERT et al., 1995; MURPHY; KUMAR, 1996, 1997; SONG; PARRY, 1996) 
were mainly concerned to critical factors for supporting the FFE management. As a result, they established a set of best practices and critical areas as well as they introduced the FFE as a complex network of elements with great impact on innovation outcomes.

Table 8. Papers within the FFE research field, but not in the Web of Science ${ }^{\odot}$.

\begin{tabular}{|l|c|}
\hline \multicolumn{1}{|c|}{ Papers } & \multicolumn{1}{|c|}{$\begin{array}{c}\text { Number of } \\
\text { Citations }\end{array}$} \\
\hline Zhang and Doll (2001) & 17 \\
\hline Hippel (1986) & 14 \\
\hline Bacon et al. (1994) & 12 \\
\hline Nobelius and Trygg (2002) & 11 \\
\hline Herstatt et al. (2004) & 8 \\
\hline Verganti (1997) & 8 \\
\hline Cooper (1997) & 7 \\
\hline Verganti (1999) & 7 \\
\hline Boeddrich (2004) & 6 \\
\hline Calantone et al. (1999) & 6 \\
\hline Cooper, Wootton and Bruce (1999) & 6 \\
\hline Goldenberg et al. (1999) & 6 \\
\hline Lilien et al. (2002) & 6 \\
\hline Cooper (1985) & 5 \\
\hline Cooper et al. (2001) & 5 \\
\hline Englund and Graham (1999) & 5 \\
\hline Leonard and Rayport (1997) & 5 \\
\hline
\end{tabular}

Table 9. List of the 10 most cited words in titles and keywords.

\begin{tabular}{|l|c|}
\hline \multicolumn{1}{|c|}{ Words } & Number of Local Citations \\
\hline Product & 357 \\
\hline Development & 303 \\
\hline Front & 303 \\
\hline Innovation & 282 \\
\hline End & 263 \\
\hline Fuzzy & 249 \\
\hline New & 231 \\
\hline Success & 207 \\
\hline Performance & 128 \\
\hline Communication & 107 \\
\hline
\end{tabular}

However, after 1997, a shift towards the use of case studies has occurred. From this moment, the majority of studies have applied qualitative approaches, reinforcing the notion that specific topics relating to the FFE are still being explored, tested and consolidated. Moreover, some case studies were also conducted to provide general descriptions of the FFE in different industries.

Afterwards, the papers were classified in terms of the research lines proposed in the classification scheme. Table 11 shows the six research lines in which the papers were sorted as well as the topics embraced by each one.

The process and information research line accounts for the majority of the sample: 42 papers. This fact suggests that the literature moved toward a specialized research agenda, not only discussing FFE models, but increasing knowledge about the FFE phases. Additionally, the ideation and screening phases have gained great attention in the last years (SCHWEITZER et al., 2012; SOUKHOROUKOVA et al., 2012).

The second research line in number of papers was organizational issues. It embraced a total of 25 papers concerning traditional and new topics: uncertainties and planning in the FFE (SONG et al., 2007; STOCKSTROM; HERSTATT, 2008; FRISHAMMAR; FLOREN; WINCENT, 2011); cross-functional integration (MOENAERT et al., 1995; VERWORN, 2006), key roles (STEVENS; BURLEY, 2003; MARKHAM et al., 2010) and dynamic capabilities (BIEDENBACH; MULLER, 2012).

The third most representative research line was tools and methods: 23 papers. This line has grown significantly in recent years, since 15 papers have been published after 2010. In addition, tools such as roadmapping (OLIVEIRA; ROZENFELD, 2010), AHP (LEE et al., 2012) and fuzzy linguistic (HUYNH; NAKAMORI, 2011) have been used in the FFE.

In the critical success factor and performance research line, the number of papers seems to have decreased in the recent years, indicating its maturity. The exception is the study of Markham et al. (2013). Furthermore, the literature has started to embrace new research topics in this line, such as the evaluation process (MARTINSUO; POSKELA, 2011).

Table 10. Classification of papers according to research methods.

\begin{tabular}{|l|c|c|}
\hline \multicolumn{1}{|c|}{ Research Methods } & Number of Papers & Percentage of the Sample \\
\hline RM1 - Literature Review & 07 & 6,0 \\
\hline RM2 - Theoretical Model or Simulation & 20 & 17,2 \\
\hline RM3 - Survey & 32 & 27,6 \\
\hline RM4 - Case Study & 52 & 44,8 \\
\hline RM5 - Action Research & 02 & 1,7 \\
\hline RM6 - Multiple Methods & 03 & 2,6 \\
\hline
\end{tabular}


Table 11. Classification according to the research lines.

\begin{tabular}{|l|l|c|c|}
\hline \multicolumn{1}{|c|}{ Research Lines } & \multicolumn{1}{|c|}{ Research Topics } & $\begin{array}{c}\text { Number of } \\
\text { Papers }\end{array}$ & $\begin{array}{c}\text { Percentage of } \\
\text { the Sample }\end{array}$ \\
\hline RL1 - Organizational issues & $\begin{array}{l}\text { lross-integration, knowledge management, formalization, complexity, } \\
\text { uncertainties and planning, equivocality, external relationships, roles, } \\
\text { degree of innovation, collaboration, capabilities and organizational } \\
\text { structure; }\end{array}$ & 25 & 22,4 \\
\hline RL2 - Process and Information & $\begin{array}{l}\text { processes, models, phases (strategy development, ideation, screening, } \\
\text { concept development, project planning), information processing and } \\
\text { decision making }\end{array}$ & 42 & 36,2 \\
\hline $\begin{array}{l}\text { RL3 - Critical success factors } \\
\text { and performance }\end{array}$ & $\begin{array}{l}\text { critical factors, evaluation process, stage-gate, performance } \\
\text { measurement and control practices; }\end{array}$ & 16 & 13,8 \\
\hline RL4 - Customer involvement & customer inputs, learning from customers/users & 09 & 7,8 \\
\hline RL5 - Tools and methods & Roadmapping, AHP, fuzzy linguistic, etc. & 23 & 19,0 \\
\hline RL6 - Others & $\begin{array}{l}\text { different FFE research topics that could not be considered in the } \\
\text { previous research lines }\end{array}$ & 01 & 0,9 \\
\hline
\end{tabular}

The customer involvement research line has provided empirical investigations to better understand customer requirements and how to capture their contributions (MAGNUSSON, 2009; PASSILA et al., 2013). It embraced a total of nine papers in the sample.

At last, there are opportunities to expand the FFE research agenda, including new themes or relating it to new trends. For example, only one paper considered sustainable practices in the FFE (PETALA et al., 2010). Although not identified in the sample, another point is the design of product service systems (PSSs), which presents new challenges for the FFE field.

\section{Conclusions}

The contribution of this paper refers to the literature review of the FFE research field. It has been noticed that the amount of FFE papers has grown in a wide range of academic journals and topics over the last years. Although studies had mainly emphasized the identification of critical factors in the early years, the number of research topics in the FFE has spread out for different lines and perspectives, which means new opportunities for investigation.

This study has limitations that should be addressed in future research, such as the limited scope of the Web of Science ${ }^{\odot}$ database and the refinement of the proposed classification scheme, mainly in terms of research lines. In addition, further bibliometric analysis need to be performed to describe research groups leaded by specific authors, which could be achieved through network analysis. The content analysis performed in this paper focused on research methods and research lines as well as it was based on a qualitative approach. It is also recommended to expand the considered topics and to apply quantitative techniques, reducing personal bias.
In conclusion, this study presents preliminary results of a project that intends to provide a complete overview of the state of the art in the front end of innovation research field.

\section{References}

AAGAARD, A. The Contribution of Innovation Strategy Development and Implementation in Active Facilitation of Pharmaceutical Front End Innovation. Systemic Practice and Action Research, v. 25, n. 6, p. 457-477, 2012. http:// dx.doi.org/10.1007/s11213-012-9234-z

AAGAARD, A.; GERTSEN, F. Supporting Radical Front End Innovation: Perceived Key Factors of Pharmaceutical Innovation. Creativity and Innovation Management, v. 20, n. 4, p. 330-346, 2011. http://dx.doi.org/10.1111/j.14678691.2011.00609.x

ACHICHE, S. et al. Fuzzy decision support for tools selection in the core front end activities of new product development. Research in Engineering Design, v. 24, n. 1, p. 1-18, 2013. http://dx.doi.org/10.1007/s00163-012-0130-4

ADAMS, D.; HUBLIKAR, S. Upgrade your new-product machine. Research Technology Management, v. 53, n. 2, p. 55-67, 2010.

AKBAR, H.; TZOKAS, N. An Exploration of New Product Development's Front-end Knowledge Conceptualization Process in Discontinuous Innovations. British Journal of Management, v. 24, n. 2, p. 245-263, 2013. http://dx.doi. org/10.1111/j.1467-8551.2011.00801.x

ALAM, I. Removing the fuzziness from the fuzzy front-end of service innovations through customer interactions. Industrial Marketing Management, v. 35, n. 4, p. 468-480, 2006. http://dx.doi.org/10.1016/j.indmarman.2005.04.004

ARMSTRONG, J. S.; OVERTON, T. S. Estimating nonresponse bias in mail surveys. Journal of Marketing Research, v. 14, n. 3, p. 396-402, 1977. http://dx.doi.org/10.2307/3150783 
ARTTO, K. et al. The integrative role of the project management office in the front end of innovation. International Journal of Project Management, v. 29, n. 4, p. 408-421, 2011. http://dx.doi.org/10.1016/j.ijproman.2011.01.008

AYAG, Z. An integrated approach to evaluating conceptual design alternatives in a new product development environment. International Journal of Production Research, v. 43, n. 4, p. 687-713, 2005. http://dx.doi.org/1 $0.1080 / 00207540512331311831$

BACKMAN, M.; BORJESSON, S.; SETTERBERG, S. Working with concepts in the fuzzy front end: exploring the context for innovation for different types of concepts at Volvo Cars. R\&D Management, v. 3, n. 1, p. 17-28, 2007.

BACON, G. et al. Managing product definition in hightechnology industries: a pilot study. California Management Review, v. 36, n. 2, p. 32-32, 1994. http:// dx.doi.org/10.2307/41165754

BERTELS, H. M. J.; KLEINSCHMIDT, E. J.; KOEN, P. A. Communities of Practice versus Organizational Climate: Which One Matters More to Dispersed Collaboration in the Front End of Innovation? Journal of Product Innovation Management, v. 28, n. 5, p. 757-772, 2011.

BESSANT, J. et al. Backing outsiders: selection strategies for discontinuous innovation. R\&D Management, v. 40, n. 4, p. 345-356, 2010. http://dx.doi.org/10.1111/j.14679310.2010.00606.x

BIEDENBACH, T. The Power of Combinative Capabilities: Facilitating the Outcome of Frequent Innovation in Pharmaceutical R\&D Projects. Project Management Journal, v. 42, n. 2, p. 63-80, 2011.

BIEDENBACH, T.; MULLER, R. Absorptive, innovative and adaptive capabilities and their impact on project and project portfolio performance. International Journal of Project Management, v. 30, n. 5, p. 621-635, 2012. http://dx.doi. org/10.1016/j.ijproman.2012.01.016

BOEDDRICH, H. J. Ideas in the workplace: a new approach towards organizing the fuzzy front end of the innovation process. Creativity and Innovation Management, v. 13, n. 4, p. 274-285, 2004. http://dx.doi.org/10.1111/j.09631690.2004.00316.x

BORJESSON, S. et al. Innovative scanning experiences from an idea generation project at Volvo Cars. Technovation, v. 26, n. 7, p. 775-783, 2006. http://dx.doi.org/10.1016/j. technovation.2005.01.005

BOSCH-REKVELDT, M. et al. Grasping project complexity in large engineering projects: The TOE (Technical, Organizational and Environmental) framework. International Journal of Project Management, v. 29, n. 6, p. 728-739, 2011. http://dx.doi.org/10.1016/j. ijproman.2010.07.008
BOTHOS, E.; APOSTOLOU, D.; MENTZAS, G. Collective intelligence with web-based information aggregation markets: The role of market facilitation in idea management. Expert Systems with Applications, v. 39, n. 1, p. 13331345, 2012. http://dx.doi.org/10.1016/j.eswa.2011.08.014

BREM, A.; VOIGT, K.-I. Integration of market pull and technology push in the corporate front end and innovation management-Insights from the German software industry. Technovation, v. 29, n. 5, p. 351-367, 2009. http://dx.doi. org/10.1016/j.technovation.2008.06.003

BRENTANI, U.; REID, S. E. The Fuzzy Front-End of Discontinuous Innovation: Insights for Research and Management. Journal of Product Innovation Management, v. 29, n. 1, p. 70-87, 2012. http://dx.doi. org/10.1111/j.1540-5885.2011.00879.x

BROERING, S. et al. The front end of innovation in an era of industry convergence: Evidence from nutraceuticals and functional foods. R\&D Management, v. 36, n. 5, p. 487-498, 2006. http://dx.doi.org/10.1111/j.14679310.2006.00449.x

BROWN, S. L.; EISENHARDT, K. M. Product development: past research, present findings, and future directions. The Academy of Management Review, v. 20, n. 2, p. 343-378, 1995.

CALANTONE, R. J.; BENEDETTO, C. A. DI; SCHMIDT, J. B. Using the analytic hierarchy process in new product screening. Journal of Product Innovation Management, v. 16, n. 1, p. 65-76, 1999. http://dx.doi.org/10.1016/S07376782(98)00036-8

CARVALHO, M. M.; FLEURY, A.; LOPES, A. P. An overview of the literature on technology roadmapping (TRM): Contributions and trends. Technological Forecasting \& Social Change, v. 80, p. 1418-1437, 2013. http://dx.doi. org/10.1016/j.techfore.2012.11.008

CHANG, H.-W.; WEI, C.-C.; LIN, R.-J. A Model for Selecting Product Ideas in Fuzzy Front End. Concurrent Engineering, v. 16, n. 2, p. 121-128, 2008. http://dx.doi. org/10.1177/1063293X08092485

CHANG, S.-L.; CHEN, C.; WEY, S. Conceptualizing, assessing, and managing front-end fuzziness in innovation/ NPD projects. R\&D Management, v. 37, n. 5, p. 469-478, 2007. http://dx.doi.org/10.1111/j.1467-9310.2007.00489.x

CLARK, K. B.; FUJIMOTO, T. Product development performance. Boston: Harvard Business School Press, 1991.

CLATWORTHY, S. Bridging the gap between brand strategy and customer experience. Managing Service Quality, v. 22, n. 2, p. 108-127, 2012. http://dx.doi. org/10.1108/09604521211218936

COHEN, W. M.; LEVINTHAL, D. A. Absorptive-capacity - a new perspective on learning and innovation. Administrative 
Science Quarterly, v. 35, n. 1, p. 128-152, 1990. http:// dx.doi.org/10.2307/2393553

COOK, D. J.; MULROW, C. D.; HAYNES, R. B. Systematic reviews: synthesis of best evidence for clinical decisions. Annals of Internal Medicine, v. 126, n. 5, p.376-380, 1997. http://dx.doi.org/10.7326/0003-4819-126-5-19970301000006

COOPER, R. G. Selecting winning new product projects: using the newprod system. Journal of Product Innovation Management, v. 2, n. 1, p. 34-44, 1985. http://dx.doi. org/10.1016/0737-6782(85)90014-1

COOPER, R. G. Winning at new products. New York: Addison-Wesley, 1993.

COOPER, R. G. Fixing the fuzzy front end of the new product process: building the business case. The Management Accounting Magazine, v. 71, p. 21-23, 1997.

COOPER, R. G.; KLEINSCHMIDT, E. J. An investigation into the new product process: steps, deficiencies, and impact. Journal of Product Innovation Management, v. 3, n. 2, p. 71-85, 1986. http://dx.doi.org/10.1016/07376782(86)90030-5

COOPER, R. G.; KLEINSCHMIDT, E. J. New products: what separates winners from losers? Journal of Product Innovation Management, v. 4, n. 3, p. 169-184, 1987. http://dx.doi.org/10.1016/0737-6782(87)90002-6

COOPER, R. G.; KLEINSCHMIDT, E. J. Determinants of timeliness in product development. Journal of Product Innovation Management, v. 11, n. 5, p. 381-396, 1994. http://dx.doi.org/10.1016/0737-6782(94)90028-0

COOPER, R. G. Predevelopment Activities Determine New Product Success. Industrial Marketing Management, v. 17, n. 3, p. 237-247, 1988. http://dx.doi.org/10.1016/00198501(88)90007-7

COOPER, R. G.; EDGETT, S. J.; KLEINSCHMIDT, E. J. Optimizing the stage-gate process: What best-practice companies do - I. Research Technology Management, v. 45, n. 5, p. 21-27, 2002.

COOPER, R. G.; EDGETT, S. J.; KLEINSCHMIDT, E. J. Portfolio management for new product development: results of an industry practices study. R\&D Management, v. 31, n. 4, p. 361-380, 2001. http://dx.doi.org/10.1111/14679310.00225

COOPER, R. G.; WOOTTON, A. B.; BRUCE, M. Requirements capture: theory and practice. Technovation, v. 18, n. 8-9, p. 497-511, 1998. http://www.sciencedirect.com/science/ article/pii/S0166497298000339

COOPER, R. G.; WOOTTON, A.; BRUCE, M. Requirements capture as process of technology-market integration. International Journal of Technology Management, v. 17 , n. 6, p. 582-596, 1999. http://dx.doi.org/10.1504/ IJTM.1999.002737
CREUSEN, M.; HULTINK, E. J.; ELING, K. Choice of consumer research methods in the front end of new product development. International Journal of Market Research, v. 55, n. 1, p. 81-104, 2013. http://dx.doi.org/10.2501/ IJMR-2013-008

DAHL, D. W.; MOREAU, P. The influence and value of analogical thinking during new product ideation.Journal of Marketing Research, v. 39, n. 1, p. 47-60, 2002. http:// dx.doi.org/10.1509/jmkr.39.1.47.18930

DWYER, L.; MELLOR, R. Organizational environment, new product process activities, and project outcomes. Journal of Product Innovation Management, v. 8, n. 1, p. 39-48, 1991. http://dx.doi.org/10.1111/1540-5885.810777

EISENHARDT, K. M. Building theories from case study research. The Academy of Management Review, v. 14, n. 4, p. 532-550, 1989.

EISENHARDT, K. M.; TABRIZI, B. N. accelerating adaptive processes: product innovation in the global computer industry. Administrative Science Quarterly, v. 40, n. 1, p. 84, 1995. http://dx.doi.org/10.2307/2393701

ELFVENGREN, K.; KORTELAINEN, S.; TUOMINEN, M. A GSS process to generate new product ideas and business concepts. International Journal of Technology Management, v. 45, n. 3-4, p. 337-348, 2009. http://dx.doi. org/10.1504/IJTM.2009.022657

ENGLUND, R.; GRAHAM, R. From experience: linking projects to strategy. Journal of Product Innovation Management, v. 16, n. 1, p. 52-64, 1999. http://dx.doi. org/10.1016/S0737-6782(98)00046-0

FLINT, D. J. Compressing new product success-to-success cycle time - Deep customer value understanding and idea generation. Industrial Marketing Management, v. 31, n. 4, p. 305-315, 2002. http://dx.doi.org/10.1016/S00198501(01)00165-1

FRISHAMMAR, J.; FLOREN, H.; WINCENT, J. Beyond Managing Uncertainty: Insights From Studying Equivocality in the Fuzzy Front End of Product and Process Innovation Projects. IEEE Transactions on Engineering Management, v. 58, n. 3, p. 551-563, 2011. http://dx.doi. org/10.1109/TEM.2010.2095017

FRISHAMMAR, J.; LICHTENTHALER, U.; KURKKIO, $M$. The front end in non-assembled product development: A multiple case study of mineral- and metal firms. Journal of Engineering And Technology Management, v. 29 , n. 4, p. 468-488, 2012. http://dx.doi.org/10.1016/j. jengtecman.2012.07.001

FRISHAMMAR, J.; LICHTENTHALER, U.; RICHTNER, A. Managing process development: key issues and dimensions in the front end. R \& D Management, v. 43, n. 3, p. 213226, 2013. 
GALBRAITH, J. R. J. R. Designing complex organizations. Boston: Addison-Wesley, 1973.

GARCIA, R.; CALANTONE, R. J. A critical look at technological innovation typology and innovativeness terminology: a literature review. Journal of Product Innovation Management, v. 19, n. 2, p. 110-132, 2002. http://dx.doi.org/10.2307/2393553

GASSMANN, O.; SANDMEIER, P.; WECHT, C. H. Extreme customer innovation in the front-end: learning from a new software paradigm. International Journal of Technology Management, v. 33, n. 1, p. 46-66, 2006. http://dx.doi. org/10.1504/IJTM.2006.008191

GERWIN, D. Integrating manufacturing into the strategic phases of new product development. California Management Review, v. 35, n. 4, p. 123-136, 1993. http://dx.doi. org/10.2307/41166758

GESCHKA, H.; LENK, T.; VIETOR, J. The idea and project database of WELLA AG. International Journal of Technology Management, v. 23, n. 5, p. 410-416, 2002. http://dx.doi.org/10.1504/IJTM.2002.003017

GILLIER, T. et al. Managing Innovation Fields in a CrossIndustry Exploratory Partnership with C-K Design Theory. Journal of Product Innovation Management, v. 27, n. 6, p. 883-896, 2010. http://dx.doi.org/10.1111/j.15405885.2010.00758.x

GISH, L.; HANSEN, C. T. A socio-technical analysis of work with ideas in NPD: an industrial case study. Research in Engineering Design, v. 24, n. 4, p. 411-427, 2013. http:// dx.doi.org/10.1007/s00163-013-0159-z

GOLDENBERG, J.; MAZURSKY, D.; SOLOMONSOURCE, S. Toward identifying the inventive templates of new products: a channeled ideation approach. Journal of Marketing Research, v. 36, n. 2, p. 200-210, 1999. http:// dx.doi.org/10.2307/3152093

GORDON, S. et al. Improving the front end of innovation with information technology. Research Technology Management, v. 51, n. 3, p. 50-59, 2008.

GRIFFIN, A. PDMA Research on new product development practices: updating trends and benchmarking best practices. Journal of Product Innovation Management, v. 14, n. 6, p. 429-458, 1997. http://dx.doi.org/10.1016/S07376782(97)00061-1

GRIFFITHS-HEMANS, J.; GROVER, R. Setting the stage for creative new products: Investigating the idea fruition process. Journal of the Academy of Marketing Science, v. 34, n. 1, p. 27-39, 2006. http://dx.doi. org/10.1177/0092070305281777

GROENVELD, P. Roadmapping integrates business and technology. Research-Technology Management, v. 40, n. 5, p. 48-55, 1997.
GROENVELD, P. Roadmapping integrates business and technology. Research-Technology Management, v. 50, n. 6, p. 49-58, 2007.

GROTE, M.; HERSTATT, C.; GEMUENDEN, H. G. CrossDivisional Innovation in the Large Corporation: Thoughts and Evidence on Its Value and the Role of the Early Stages of Innovation. Creativity and Innovation Management, v. 21, n. 4, p. 361-375, 2012. http://dx.doi.org/10.1111/j.14678691.2012.00652.x

HAMMEDI, W.; VAN RIEL, A. C. R.; SASOVOVA, Z. Antecedents and Consequences of Reflexivity in New Product Idea Screening. Journal of Product Innovation Management, v. 28, n. 5, p. 662-679, 2011.

HANNOLA, L. et al. Utilizing front-end-of-innovation concepts in software development. Industrial Management \& Data Systems, v. 109, n. 7, p. 898-915, 2009. http:// dx.doi.org/10.1108/02635570910982265

HEISING, W. The integration of ideation and project portfolio management - A key factor for sustainable success. International Journal of Project Management, v. 30, n. 5, p. 582-595, 2012. http://dx.doi.org/10.1016/j. ijproman.2012.01.014

HESMER, A. et al. Supporting the ideation processes by a collaborative online based toolset. International Journal of Technology Management, v. 55, n. 3-4, p. 218-225, 2011. http://dx.doi.org/10.1504/IJTM.2011.041948

HERSTATT, C.; VERWORN, B.; NAGAHIRA, A. Reducing project related uncertainty in the "fuzzy front end" of innovation: a comparison of German and Japanese product innovation projects. International Journal of Product Development, v. 1, n. 1, p. 43-65, 2004. http://dx.doi. org/10.1504/IJPD.2004.004890

HIPPEL, E. VON. Lead users: a source of novel product concepts. Management Science, v. 32, n. 7, p. 691-804, 1986. http://dx.doi.org/10.1287/mnsc.32.7.791

HONG, P.; NAHM, A. Y.; DOLL, W. J. The role of project target clarity in an uncertain project environment. International Journal of Operations \& Production Management, v. 24, n. 11-12, p. 1269-1291, 2004. http:// dx.doi.org/10.1108/01443570410569047

HUYNH, V.-N.; NAKAMORI, Y. A linguistic screening evaluation model in new product development. IEEE TransactionsonEngineering Management, v. 58, n. 1, p. 165-175, 2011. http://dx.doi.org/10.1109/ TEM.2009.2028326

IM, S.; MONTOYA-WEISS, M. M.; WORKMAN JUNIOR, J. P. Antecedents and Consequences of Creativity in Product Innovation Teams. Journal of Product Innovation Management, v. 30, n. 1, p. 170-185, 2013. http://dx.doi. org/10.1111/j.1540-5885.2012.00887.x 
KHURANA, A.; ROSENTHAL, S. R. Integrating the fuzzy front end of new product development. Sloan Management Review, v. 38, n. 2, p. 103-120, 1997.

KHURANA, A.; ROSENTHAL, S. R. Towards holistic front ends in new product development. Journal of Product Innovation Management, v. 15, n. 1, p. 57-74, 1998. http:// onlinelibrary.wiley.com/doi/10.1111/1540-5885.1510057/ abstract

KIJKUIT, B. et al. The Organizational Life of an Idea: Integrating Social Network, Creativity and DecisionMaking Perspectives. Journal of Management Studies, v. 44, n. 6, p. 863-882, 2007. http://dx.doi.org/10.1111/j.14676486.2007.00695.x

KIJKUIT, B.; VAN DEN ENDE, J. With a Little Help from Our Colleagues: A Longitudinal Study of Social Networks for Innovation. Organization Studies, v. 31, n. 4, p. 451479, 2010. http://dx.doi.org/10.1177/0170840609357398

KIM, J.; WILEMON, D. Focusing the fuzzy front-end in new product development. R \& D Management, v. 32, n. 4, p. 269-279, 2002. http://dx.doi.org/10.1111/1467-9310.00259

KOEN, P. et al. Providing clarity and a common language to the "fuzzy front end". Research Technology Management, v. 44, n. 2, p. 46-55, 2001.

KOEN, P. A. et al. Fuzzy front end: effective methods, tools and techniques. In: BELLIVEAU, B.; GRIFFIN, A.; SOMEMYER, S. (Ed.). The PDMA toolbook for new product development. Nova York: John Wiley \& Sons, 2002. cap. 1, p. 5-35.

KRISTENSSON, P.; MAGNUSSON, P. R. Tuning Users' Innovativeness During Ideation. Creativity and Innovation Management, v. 19, n. 2, p. 147-159, 2010. http://dx.doi. org/10.1111/j.1467-8691.2010.00552.x

KURKKIO, M.; FRISHAMMAR, J.; LICHTENTHALER, U. Where process development begins: A multiple case study of front end activities in process firms. Technovation, v. 31, n. 9, p. 490-504, 2011. http://dx.doi.org/10.1016/j. technovation.2011.05.004

LANGERAK, F.; HULTINK, E. J.; ROBBEN, H. S. J. The role of predevelopment activities in the relationship between market orientation and performance. R \& D Management, v. 34, n. 3, p. 295-309, 2004. http://dx.doi.org/10.1111/ j.1467-9310.2004.00340.x

LEE, C. et al. Evaluation of new service concepts using rough set theory and group analytic hierarchy process. Expert Systems with Applications, v. 39, n. 3, p. 3404-3412, 2012. http://dx.doi.org/10.1016/j.eswa.2011.09.028

LEE, H.; KIM, C.; PARK, Y. Evaluation and management of new service concepts: An ANP-based portfolio approach. Computers \& Industrial Engineering, v. 58, n. 4, p. 535-543, 2010. http://dx.doi.org/10.1016/j.cie.2009.11.016
LEONARD, D.; RAYPORT, J. Spark innovation through empathic design. Harvard Business Review, v. 75, n. 6, p. 102-113, 1997.

LILIEN, G. L. et al. Performance assessment of the lead user idea-generation process for new product development. Management Science, v. 48, n. 8, p. 1042-1059, 2002. http://dx.doi.org/10.1287/mnsc.48.8.1042.171

LIN, C. T.; CHEN, C. T. New product Go/No-Go evaluation at the front end: A fuzzy linguistic approach. IEEE Transactions on Engineering Management, v. 51, n. 2, p. 197-207, 2004. http://dx.doi.org/10.1109/TEM.2003.822458

LOCH, C. H. et al. Selecting R\&D projects at BMW: A case study of adopting mathematical programming models. IEEE Transactions on Engineering Management, v. 48, n. 1, p. 70-80, 2001. http://dx.doi.org/10.1109/17.913167

MAGNUSSON, P. R. Exploring the Contributions of Involving Ordinary Users in Ideation of Technology-Based Services. Journal of Product Innovation Management, v. 26, n. 5, p. 578-593, 2009. http://dx.doi.org/10.1111/j.15405885.2009.00684.x

MARKHAM, S. K. et al. The Valley of Death as Context for Role Theory in Product Innovation. Journal of Product Innovation Management, v. 27, n. 3, p. 402-417, 2010. http://dx.doi.org/10.1111/j.1540-5885.2010.00724.x

MARKHAM, S. K. et al. The Impact of Front-End Innovation Activities on Product Performance. Journal of Product Innovation Management, v. 30, n. 1, p. 77-92, 2013. http:// dx.doi.org/10.1111/jpim.12065

MARTINSUO, M.; POSKELA, J. Use of Evaluation Criteria and Innovation Performance in the Front End of Innovation. Journal of Product Innovation Management, v. 28, n. 6, SI, p. 896-914, 2011.

MASSEY, A. P.; MONTOYA-WEISS, M. M.; O’DRISCOLL, T. M. Performance-centered design of knowledge-intensive processes. Journal of Management Information Systems, v. 18, n. 4, p. 37-58, 2002a.

MASSEY, A. P.; MONTOYA-WEISS, M. M.; O'DRISCOLL, T. M. Knowledge management in pursuit of performance: Insights from Nortel Networks. Mis Quarterly, v. 26, n. 3, p. 269-289, 2002b. http://dx.doi.org/10.2307/4132333

MATHEWS, S. Innovation Portfolio Architecture. ResearchTechnology Management, v. 53, n. 6, p. 30-40, 2010.

MOENAERT, R. K. et al. R-and-D marketing communication during the fuzzy front-end. IEEE Transactions on Engineering Management, v. 42, n. 3, p. 243-258, 1995. http://dx.doi.org/10.1109/17.403743

MONTOYA-WEISS, M. M.; O’DRISCOLL, T. M. From experience: Applying performance support technology in the fuzzy front end. Journal of Product Innovation Management, v. 17, n. 2, p. 143-161, 2000. http:// 
onlinelibrary.wiley.com/doi/10.1111/1540-5885.1720143/ abstract

MURPHY, S. A.; KUMAR, V. The role of predevelopment activities and firm attributes in new product success. Technovation, v. 16, n. 8, p. 431-441, 1996. http://dx.doi. org/10.1016/0166-4972(96)00028-4

MURPHY, S. A.; KUMAR, V. The front end of new product development: A Canadian survey. R \& D Management, v. 27, n. 1, p. 5-15, 1997. http://dx.doi.org/10.1111/14679310.00038

NOBELIUS, D.; TRYGG, L. Stop chasing the front end process - management of the early phases in product development projects. International Journal of Project Management, v. 20, n. 5, p. 331-340, 2002. http://dx.doi.org/10.1016/ S0263-7863(01)00030-8

OH, J.; YANG, J.; LEE, S. Managing uncertainty to improve decision-making in NPD portfolio management with a fuzzy expert system. Expert Systems with Applications, v. 39, n. 10, p. 9868-9885, 2012. http://dx.doi.org/10.1016/j. eswa.2012.02.164

$\mathrm{OKUBO}, \mathrm{Y}$. Bibliometric indicators and analysis of research systems: methods and examples. Paris: OECD Publishing, 1997. http://dx.doi.org/10.1787/208277770603

OLIVEIRA, M. G.; ROZENFELD, H. Integrating technology roadmapping and portfolio management at the front-end of new product development. Technological Forecasting and Social Change, v. 77, n. 8, p. 1339-1354, 2010. http:// dx.doi.org/10.1016/j.techfore.2010.07.015

OLIVEIRA, M. G. et al. A starting point for addressing product innovativeness in the fuzzy front-end. International Journal of Technology Intelligence and Planning, v. 7, n. 4, p. 309-326, 2011. http://dx.doi.org/10.1504/ IJTIP.2011.045092

OZER, M. Factors which influence decision making in new product evaluation. European Journal of Operational Research, v. 163, n. 3, p. 784-801, 2005. http://dx.doi. org/10.1016/j.ejor.2003.11.002

OZER, M. Reducing the demand uncertainties at the fuzzyfront-end of developing new online services. Research Policy, v. 36, n. 9, p. 1372-1387, 2007. http://dx.doi. org/10.1016/j.respol.2007.06.001

PARJANEN, S.; HENNALA, L.; KONSTI-LAAKSO, S. Brokerage functions in a virtual idea generation platform: Possibilities for collective creativity? InnovationManagement Policy \& Practice, v. 14, n. 3, p. 363-374, 2012. http://dx.doi.org/10.5172/impp.2012.14.3.363

PASSILA, A. et al. Interpretative dimension of userdriven service innovation Forum Theatre in facilitating renewal in Finnish public health care. Baltic Journal of Management, v. 8, n. 2, p. 166-182, 2013. http://dx.doi. org/10.1108/17465261311310009
PETALA, E. et al. The role of new product development briefs in implementing sustainability: a case study. Journal of Engineeringand Technology Management,v. 27, n. 3-4, p. 172-182, 2010. http://dx.doi.org/10.1016/j. jengtecman.2010.06.004

POSKELA, J.; MARTINSUO, M. Management Control and Strategic Renewal in the Front End of Innovation. Journal of Product Innovation Management, v. 26, n. 6, p. 671-684, 2009. http://dx.doi.org/10.1111/j.1540-5885.2009.00692.x

RAMOS-RODRÍGUEZ, A. R.; RUÍZ-NAVARRO, J. Changes in the intellectual structure of strategic management research: a bibliometric study of the strategic management journal, 1980-2000. Strategic Management Journal, v. 25, n. 10, p. 981-1004, 2004. http://dx.doi.org/10.1002/smj.397

RAUNIAR, R.; RAWSKI, G. Organizational structuring and project team structuring in integrated product development project. International Journal of Production Economics, v. 135, n. 2, p. 939-952, 2012. http://dx.doi.org/10.1016/j. ijpe.2011.11.009

REID, S. E.; BRENTANI, U. The fuzzy front end of new product development for discontinuous innovations: A theoretical model. Journal of Product Innovation Management, v. 21, n. 3, p. 170-184, 2004. http://dx.doi. org/10.1111/j.0737-6782.2004.00068.x

REID, S. E.; BRENTANI, U. Market Vision and the Front End of NPD for Radical Innovation: The Impact of Moderating Effects. Journal of Product Innovation Management, v. 29, n. 1, p. 124-139, 2012. http://dx.doi.org/10.1111/j.15405885.2012.00955.x

REINERTSEN, D. G. Taking the fuzziness out of the fuzzy front end. Research-Technology Management, v. 42, n. 6, p. 25-31, 1999.

RICE, M. P. et al. Radical innovation: triggering initiation of opportunity recognition and evaluation. $\mathbf{R} \& \mathbf{D}$ Management, v. 31, n. 4, p. 409-420, 2001. http://dx.doi. org/10.1111/1467-9310.00228

RIEL, A.; NEUMANN, M.; TICHKIEWITCH, S. Structuring the early fuzzy front-end to manage ideation for new product development. Cirp Annals-Manufacturing Technology, v. 62, n. 1, p. 107-110, 2013. http://dx.doi.org/10.1016/j. cirp.2013.03.128

ROSENTHAL, S. R.; CAPPER, M. Ethnographies in the front end: Designing for enhanced customer experiences. Journal of Product Innovation Management, v. 23, n. 3, p. 215-237, 2006. http://dx.doi.org/10.1111/j.15405885.2006.00195.x

RUBENSTEIN, A. H. At the Front-End of the R-And-D/ Innovation Process - Idea Development and Entrepreneurship. International Journal of Technology Management, v. 9, n. 5-7, p. 652-677, 1994. 
RUSSELL, R. K.; TIPPETT, D. D. Critical Success Factors for the Fuzzy Front End of Innovation in the Medical Device Industry. EMJ-Engineering Management Journal, v. 20, n. 3, p. 36-43, 2008.

SALOMO, S.; WEISE, J.; GEMUENDEN, H. G. NPD planning activities and innovation performance: The mediating role of process management and the moderating effect of product innovativeness. Journal of Product Innovation Management, v. 24, n. 4, p. 285-302, 2007. http://dx.doi. org/10.1111/j.1540-5885.2007.00252.x

SANDMEIER, P. Customer integration strategies for innovation projects: anticipation and brokering. International Journal of Technology Management, v. 48, n. 1, p. 1-23, 2009. http://dx.doi.org/10.1504/IJTM.2009.024597

SCHIRR, G. R. Flawed Tools: the efficacy of group research methods to generate customer ideas. Journal of Product Innovation Management, v. 29, n. 3, p. 473-488, 2012.

SCHOONMAKER, M.; CARAYANNIS, E.; RAU, P. The role of marketing activities in the fuzzy front end of innovation: a study of the biotech industry. Journal of Technology Transfer, v. 38, n. 6, p. 850-872, 2013. http://dx.doi. org/10.1007/s10961-012-9296-1

SCHRODER, H. H.; JETTER, A. J. M. Integrating market and technological knowledge in the fuzzy front end: an FCMbased action support system. International Journal of Technology Management, v. 26, n. 5-6, p. 517-539, 2003. http://dx.doi.org/10.1504/IJTM.2003.003421

SCHWEITZER, F. M. et al. Crowdsourcing Leveraging Innovation through Online Idea Competitions. ResearchTechnology Management, v. 55, n. 3, p. 32-38, 2012. http:// dx.doi.org/10.5437/08956308X5503055

SMITH, P. G.; REINERTSEN, D. G. Developing products in half the time. New York: Van Nostrand Reinhold, 1991.

SMITH, G. R.; HERBEIN, W. C.; MORRIS, R. C. Front-end innovation at alliedsignal and alcoa. Research-Technology Management, v. 42, n. 6, p. 15-24, 1999.

SONG, X. M.; PARRY, M. E. What separates Japanese new product winners from losers. Journal of Product Innovation Management, v. 13, n. 5, p. 422-439, 1996. http://onlinelibrary.wiley.com/doi/10.1111/15405885.1350422/abstract

SONG, Y.-I. et al. Managing uncertainty and ambiguity in frontier R\&D projects: A Korean case study. Journal of Engineering and Technology Management, v. 24, n. 3, p. 231-250, 2007. http://dx.doi.org/10.1016/j. jengtecman.2007.05.001

SOUKHOROUKOVA, A.; SPANN, M.; SKIERA, B. Sourcing, Filtering, and Evaluating New Product Ideas: An Empirical Exploration of the Performance of Idea Markets. Journal of Product Innovation Management, v. 29, n. 1, p. 100-112, 2012. http://dx.doi.org/10.1111/j.1540-5885.2011.00881.x
SPANJOL, J.; QUALLS, W. J.; ROSA, J. A. How Many and What Kind? The Role of Strategic Orientation in New Product Ideation. Journal of Product Innovation Management, v. 28, n. 2, p. 236-250, 2011. http://dx.doi. org/10.1111/j.1540-5885.2010.00794.X

STEPHEN, R.; KHURANA, A.; ROSENTHAL, S. R. Integrating the fuzzy front end of new product development. Sloan Management Review, v. 38, n. 2, p. 103-120, 1997.

STEVENS, G. A.; BURLEY, J. Piloting the rocket of radical innovation. Research-Technology Management, v. 46, n. 2, p. 16-25, 2003.

STOCKSTROM, C.; HERSTATT, C. Planning and uncertainty in new product development. R\&D Management, v. 38, n. 5, p. 480-490, 2008.

VAN AKEN, J. E.; WEGGEMAN, M. P. Managing learning in informal innovation networks: overcoming the Daphnedilemma. R \& D Management, v. 30, n. 2, p. 139-149, 2000. http://dx.doi.org/10.1111/1467-9310.00164

VAN DEN HENDE, E. A.; SCHOORMANS, J. P. L. The Story Is As Good As the Real Thing: Early Customer Input on Product Applications of Radically New Technologies. Journal of Product Innovation Management, v. 29, n. 4, p. 655-666, 2012. http://dx.doi.org/10.1111/j.15405885.2012.00931.x

VAN RIEL, A. C. R. et al. Technology-based service proposal screening and decision-making effectiveness. Management Decision, v. 49, n. 5, p. 762-783, 2011. http://dx.doi. org/10.1108/00251741111130841

VAN ZYL, H.; DU PREEZ, N. D.; SCHUTTE, C. Utilizing formal innovation models to support and guide industry innovation projects. South African Journal of Industrial Engineering, v. 18, n. 2, p. 203-219, 2007.

VERGANTI, R. Leveraging on systemic learning to manage the early phases of product innovation projects. R\&D Management, v. 27, n. 4, p. 377-392, 1997. http://dx.doi. org/10.1111/1467-9310.00072

VERGANTI, R. planned flexibility: linking anticipation and reaction in product development projects. Journal of Product Innovation Management, v. 16, n. 4, p. 363-376, 1999. http://dx.doi.org/10.1016/S0737-6782(98)00067-8

VERYZER, R. W. Discontinuous innovation and the new product development process. Journal of Product Innovation Management, v. 15, n. 4, p. 304-321, 1998. http://dx.doi.org/10.1016/S0737-6782(97)00105-7

VERWORN, B. How German measurement and control firms integrate market and technological knowledge into the front end of new product development. International Journal of Technology Management, v. 34, n. 3-4, p. 379-389, 2006. http://dx.doi.org/10.1504/IJTM.2006.009465 
VERWORN, B. A structural equation model of the impact of the "fuzzy front end" on the success of new product development. Research Policy, v. 38, n. 10, p. 1571-1581, 2009. http://dx.doi.org/10.1016/j.respol.2009.09.006

VERWORN, B.; HERSTATT, C.; NAGAHIRA, A. The fuzzy front end of Japanese new product development projects: impact on success and differences between incremental and radical projects. R \& D Management, v. 38, n. 1, p. 1-19, 2008. http://dx.doi.org/10.1111/j.1467-9310.2007.00492.x

VLIEGEN, H. J. W.; VANMAL, H. H. Innovation and development strategy. International Journal of Computer Integrated Manufacturing, v. 4, n. 3, p. 169-175, 1991. http://dx.doi.org/10.1080/09511929108944492

WAGNER, S. M. Tapping Supplier Innovation. Journal of Supply Chain Management, v. 48, n. 2, p. 37-52, 2012. http://dx.doi.org/10.1111/j.1745-493X.2011.03258.x

WEI, C.-C. C.-C.; CHANG, H.-W. H.-W. A new approach for selecting portfolio of new product development projects.
Expert Systems withApplications, v. 38, n. 1, p. 429-434, 2011.

WHEELWRIGHT, S. C.; CLARK, K. B. Revolutionizing product development: quantum leaps in speed, efficiency, and quality. New York: The Free Press, 1992. p. 364.

WILLIAMS, T.; SAMSET, K. Issues in Front-End Decision Making on Projects. Project Management Journal, v. 41, n. 2, p. 38-49, 2010. http://dx.doi.org/10.1002/pmj.20160

WU, M. F.; CHANG, P. L. Assessing mechanism for predevelopment stage of new product development by stagegate model. African Journal of Business Management, v. 5, n. 6, p. 2445-2454, 2011.

YIN, R. Case study research: design and methods. Beverly Hills: Sage Publishing, 1994.

ZHANG, Q.; DOLL, W. J. The fuzzy front end and success of new product development: a causal model. European Journal of Innovation Management, v. 4, n. 2, p. 95-112, 2001. http://dx.doi.org/10.1108/14601060110390602 
Appendix 1. The 116 papers selected for the sample.

\begin{tabular}{|c|c|c|c|}
\hline & Authors & ResearchMethod & ResearchLine \\
\hline 1 & Aagaard (2012) & RM5 & RL3 \\
\hline 2 & Aagaard and Gertsen (2011) & RM4 & RL3 \\
\hline 3 & Achiche et al. (2013) & RM4 & RL5 \\
\hline 4 & Adams and Hublikar (2010) & RM2 & RL2 \\
\hline 5 & Akbar and Tzokas (2013) & RM4 & RL1 \\
\hline 6 & Van Aken and Weggeman (2000) & RM1 & RL1 \\
\hline 7 & Alam (2006) & RM4 & RL4 \\
\hline 8 & Artto et al. (2011) & RM4 & RL1 \\
\hline 9 & Ayag (2005) & RM2 & RL5 \\
\hline 10 & Backman, Borjesson and Setterberg (2007) & RM4 & RL2 \\
\hline 11 & Bertels, Kleinschmidt e Koen (2011) & RM3 & RL1 \\
\hline 12 & Bessant et al. (2010) & RM2 & RL2 \\
\hline 13 & Biedenbach (2011) & RM4 & RL1 \\
\hline 14 & Biedenbach and Muller (2012) & RM6 & RL1 \\
\hline 15 & Borjesson et al. (2006) & RM4 & RL5 \\
\hline 16 & Bosch-Rekveldt et al. (2011) & RM4 & RL1 \\
\hline 17 & Bothos, Apostolou and Mentzas (2012) & RM3 & RL5 \\
\hline 18 & Brem and Voigt (2009) & RM4 & RL2 \\
\hline 19 & Brentani and Reid (2012) & RM2 & RL2 \\
\hline 20 & Broering et al. (2006) & RM6 & RL2 \\
\hline 21 & Chang, Wei and Lin (2008) & RM2 & RL2 \\
\hline 22 & Chang, Chen and Wey (2007) & RM4 & RL3 \\
\hline 23 & Clatworthy (2012) & RM5 & RL2 \\
\hline 24 & Cooper (1988) & RM2 & RL2 \\
\hline 25 & Cooper, Edgett and Kleinschmidt (2002) & RM2 & RL3 \\
\hline 26 & Cooper, Wootton and Bruce (1998) & RM4 & RL2 \\
\hline 27 & Cooper, Wootton and Bruce (1999) & RM2 & RL2 \\
\hline 28 & Creusen, Hultink and Eling (2013) & RM3 & RL5 \\
\hline 29 & Dahl and Moreau (2002) & RM4 & RL2 \\
\hline 30 & Elfvengren, Kortelainen and Tuominen (2009) & RM4 & RL2 \\
\hline 31 & Flint (2002) & RM2 & RL4 \\
\hline 32 & Frishammar, Floren and Wincent (2011) & RM4 & RL1 \\
\hline 33 & Frishammar, Lichtenthaler and Kurkkio (2012) & RM4 & RL2 \\
\hline 34 & Frishammar, Lichtenthaler and Richtner (2013) & RM4 & RL2 \\
\hline 35 & Gassmann, Sandmeier and Wecht (2006) & RM4 & RL4 \\
\hline 36 & Gerwin (1993) & RM4 & RL1 \\
\hline 37 & Geschka, Lenk and Vietor (2002) & RM4 & RL2 \\
\hline 38 & Gillier et al. (2010) & RM4 & RL5 \\
\hline 39 & Gish and Hansen (2013) & RM4 & RL2 \\
\hline 40 & Gordon et al. (2008) & RM2 & RL5 \\
\hline 41 & Griffiths-Hemans and Grover (2006) & RM6 & RL2 \\
\hline 42 & Groenveld (1997) & RM4 & RL5 \\
\hline 43 & Groenveld (2007) & RM4 & RL5 \\
\hline 44 & Grote, Herstatt and Gemuenden (2012) & RM3 & RL1 \\
\hline 45 & Hammedi, Van Riel and Sasovova (2011) & RM3 & RL2 \\
\hline 46 & Hannola et al. (2009) & RM4 & RL2 \\
\hline 47 & Heising (2012) & RM1 & RL5 \\
\hline 48 & Van Den Hende and Schoormans (2012) & RM4 & RL5 \\
\hline 49 & Hesmer et al. (2011) & RM2 & RL2 \\
\hline
\end{tabular}


Appendix 1. Continued...

\begin{tabular}{|c|c|c|c|}
\hline & Authors & ResearchMethod & ResearchLine \\
\hline 50 & Hong et al. (2004) & RM3 & RL1 \\
\hline 51 & Huynh and Nakamori (2011) & RM4 & RL5 \\
\hline 52 & Im, Montoya-Weiss and Workman Junior (2013) & RM3 & RL1 \\
\hline 53 & Khurana and Rosenthal (1998) & RM4 & RL2 \\
\hline 54 & Kijkuit et al. (2007) & RM2 & RL2 \\
\hline 55 & Kijkuit and Van Den Ende (2010) & RM4 & RL1 \\
\hline 56 & Kim and Wilemon (2002) & RM1 & RL2 \\
\hline 57 & Koen et al. (2001) & RM3 & RL2 \\
\hline 58 & Kristensson and Magnusson (2010) & RM3 & RL4 \\
\hline 59 & Kurkkio, Frishammar and Lichtenthaler (2011) & RM4 & RL2 \\
\hline 60 & Langerak, Hultink and Robben (2004) & RM3 & RL3 \\
\hline 61 & Lee et al. (2012) & RM2 & RL5 \\
\hline 62 & Lee et al. (2010) & RM4 & RL5 \\
\hline 63 & Lin and Chen (2004) & RM4 & RL5 \\
\hline 64 & Loch et al. (2001) & RM4 & RL5 \\
\hline 65 & Magnusson (2009) & RM2 & RL4 \\
\hline 66 & Markham et al. (2010) & RM3 & RL1 \\
\hline 67 & Markham et al. (2013) & RM3 & RL3 \\
\hline 68 & Martinsuo and Poskela (2011) & RM3 & RL3 \\
\hline 69 & Massey, Montoya-Weiss and O'driscoll (2002a) & RM4 & RL1 \\
\hline 70 & Massey, Montoya-Weiss and O'driscoll (2002b) & RM4 & RL5 \\
\hline 71 & Mathews (2010) & RM4 & RL5 \\
\hline 72 & Moenaert et al. (1995) & RM3 & RL1 \\
\hline 73 & Montoya-Weiss and O'driscoll (2000) & RM4 & RL2 \\
\hline 74 & Murphy and Kumar (1996) & RM3 & RL3 \\
\hline 75 & Murphy and Kumar (1997) & RM3 & RL3 \\
\hline 76 & Oh, Yang and Lee (2012) & RM2 & RL5 \\
\hline 77 & Oliveira and Rozenfeld (2010) & RM4 & RL5 \\
\hline 78 & Ozer (2005) & RM1 & RL3 \\
\hline 79 & Ozer (2007) & RM3 & RL1 \\
\hline 80 & Parjanen, Hennala and Konsti-Laakso (2012) & RM4 & RL4 \\
\hline 81 & Passila et al. (2013) & RM4 & RL4 \\
\hline 82 & Petala et al. (2010) & RM1 & RL6 \\
\hline 83 & Poskela and Martinsuo (2009) & RM3 & RL3 \\
\hline 84 & Rauniar and Rawski (2012) & RM3 & RL1 \\
\hline 85 & Reid and Brentani (2004) & RM2 & RL2 \\
\hline 86 & Reid and Brentani (2012) & RM3 & RL3 \\
\hline 87 & Reinertsen (1999) & RM2 & RL2 \\
\hline 88 & Rice et al. (2001) & RM4 & RL1 \\
\hline 89 & Riel et al. (2013) & RM3 & RL2 \\
\hline 90 & Van Riel et al. (2011) & RM4 & RL2 \\
\hline 91 & Rosenthal and Capper (2006) & RM4 & RL4 \\
\hline 92 & Rubenstein (1994) & RM3 & RL2 \\
\hline 93 & Russell and Tippett (2008) & RM4 & RL3 \\
\hline 94 & Salomo, Weise and Gemuenden (2007) & RM3 & RL1 \\
\hline 95 & Sandmeier (2009) & RM4 & RL4 \\
\hline 96 & Schirr (2012) & RM1 & RL2 \\
\hline 97 & Schoonmaker, Carayannis and Rau (2013) & RM3 & RL1 \\
\hline 98 & Schroder and Jetter (2003) & RM2 & RL2 \\
\hline 99 & Schweitzer et al. (2012) & RM4 & RL2 \\
\hline
\end{tabular}


Appendix 1. Continued...

\begin{tabular}{|l|l|c|c|}
\hline \multicolumn{1}{|c|}{ Authors } & ResearchMethod & ResearchLine \\
\hline 100 & Smith, Herbein and Morris (1999) & RM4 & RL2 \\
\hline 101 & Song and Parry (1996) & RM3 & RL3 \\
\hline 102 & Song et al. (2007) & RM4 & RL2 \\
\hline 103 & Soukhoroukova, Spann and Skiera (2012) & RM4 & RL2 \\
\hline 104 & Spanjol, Qualls and Rosa (2011) & RM4 & RL2 \\
\hline 105 & Khurana and Rosenthal (1997) & RM3 & RL1 \\
\hline 106 & Stevens and Burley (2003) & RM3 & RL1 \\
\hline 107 & Stockstrom and Herstatt (2008) & RM3 & RL3 \\
\hline 108 & Verworn (2006) & RM3 & RL3 \\
\hline 109 & Verworn (2009) & RM3 & RL2 \\
\hline 110 & Verworn, Herstatt and Nagahira (2008) & RM3 & RL1 \\
\hline 111 & Vliegen and Vanmal (1991) & RM2 & RL5 \\
\hline 112 & Wagner (2012) & RM1 & RL2 \\
\hline 113 & Wei and Chang (2011) & RM4 & RL5 \\
\hline 114 & Williams and Samset (2010) & RM4 & RL2 \\
\hline 115 & Wu and Chang (2011) & & RM \\
\hline 116 & Van Zyl, Du Preez and Schutte (2007) & RM & RM \\
\hline
\end{tabular}

